Branimir N. Grgur ${ }^{1 *}$, Milica M. Gvozdenović ${ }^{1}$, Branimir Z. Jugović ${ }^{2}$

${ }^{1}$ University of Belgrade, Faculty of Technology and Metallurgy, Belgrade, Serbia, ${ }^{2}$ Institute of Technical Sciences of the Serbian Academy of Sciences and Arts, Belgrade, Serbia
Scientific paper

ISSN 0351-9465, E-ISSN 2466-2585

UDC:620.193.194:669.127.5

doi:10.5937/ZasMat1604597G

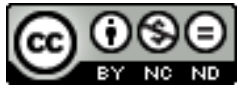

Zastita Materijala 57 (4)

597 - 599 (2016)

\title{
The influence of light on corrosion of polyaniline coated mild steel
}

\begin{abstract}
The influence of light of the mild steel corrosion in $3 \% \mathrm{NaCl}$ solution with polyaniline coating based on the possibilities that polyaniline can generate photoelectrons, even in the laboratory conditions has been investigated.
\end{abstract}

Keywords: mild steel; corrosion; polyaniline; photoelectrochemistry.

\section{INTRODUCTION}

Conducting polymers (CP) [1] exhibit electroactive properties in corrosion protection of different metals [2-5]. Up to now, many mechanisms of action have been proposed like, barrier effect, passivation of metal surfaces, auto-dedoping mechanism etc. [2,3]. Still, there is a lot of ambiguities about the real protection mechanism. In the few papers, it has been suggested that polyaniline can produce the photoelectric effect [6-9].

Hence, in this paper, we investigated the corrosion behavior of the mild steel (MS) and the mild steel with polyaniline polymer coatings based on the possibilities that polyaniline can generate photoelectrons.

\section{EXPERIMENTAL}

Electrochemical synthesis of PANI on the mild steel (AISI 1212) electrode was performed at a constant current density of $1.5 \mathrm{~mA} \mathrm{~cm}^{-2}$ from aqueous solution of $0.5 \mathrm{M} \mathrm{Na-benzoate} \mathrm{(p.a.}$ Merck) and 0.25 M aniline (p.a. Aldrich) [10]. Prior to use aniline was distilled under argon atmosphere. All used electrolytes were prepared with bidistilled water. Mild steel electrode, was mechanically polished with fine emery papers $(2 / 0$, $3 / 0$ and $4 / 0$, respectively), degreased in acetone and pickled in the hydrochloric acid with the addition of $0.5 \%$ urotropine (hexa-methylenetetramine).

${ }^{*}$ Corresponding author: Branimir N. Grgur

E-mail: BNGrgur@tmf.bg.ac.rs

Paper received: 23. 07. 2016.

Paper accepted: 18. 08. 2016.

Paper is available on the website:

www.idk.org.rs/journal
Experiments were performed at ambient temperature $\left(23^{\circ} \mathrm{C}\right)$. Saturated calomel electrode (SCE) was used as reference, while Pt mesh served as the counter electrode. All the measurements were carried out using PAR 273A potentiostat/galvanostat and PAR Lock-in amplifier M5031 interfaced to a PC.

Photoelectrochemical measurements were conducted using a tungsten bulb $(200 \mathrm{~W})$ with a light intensity of $\sim 4 \mathrm{~mW} \mathrm{~cm}{ }^{-2}$ measured by an Amaprobe SOLAR- 100 Meter.

\section{RESULTS AND DISCUSSION}

Figure 1 represents a Nyquist plot of the mild steel electrode in $3 \% \mathrm{NaCl}$ at the corrosion potential $\left(E_{\text {corr }}=-0.642 \mathrm{~V}\right)$ under dark conditions and illumination $\left(4 \mathrm{~mW} \mathrm{~cm} \mathrm{~cm}^{-2}\right)$. As it can be seen illumination practically does not have any effect on the corrosion processes of mild steel at the corrosion potential.

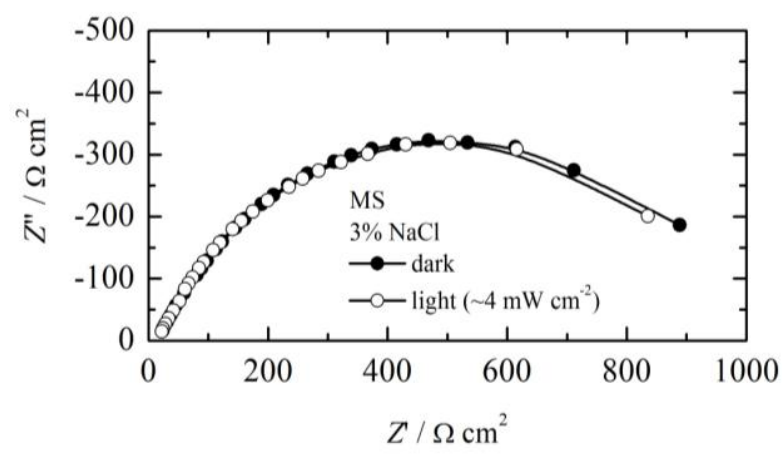

Figure 1 - Nyquist plot of the mild steel electrode in $3 \% \mathrm{NaCl}$ under illumination $\left(4 \mathrm{~mW} \mathrm{~cm}^{-2}\right)$ and in dark conditions at corrosion potential.

Practically, the same results were obtained recording the polarization curves, as shown in Fig. 
2. The determined corrosion current density under illumination and in the dark conditions was the same $20 \mu \mathrm{A} \mathrm{cm}^{-2}$.

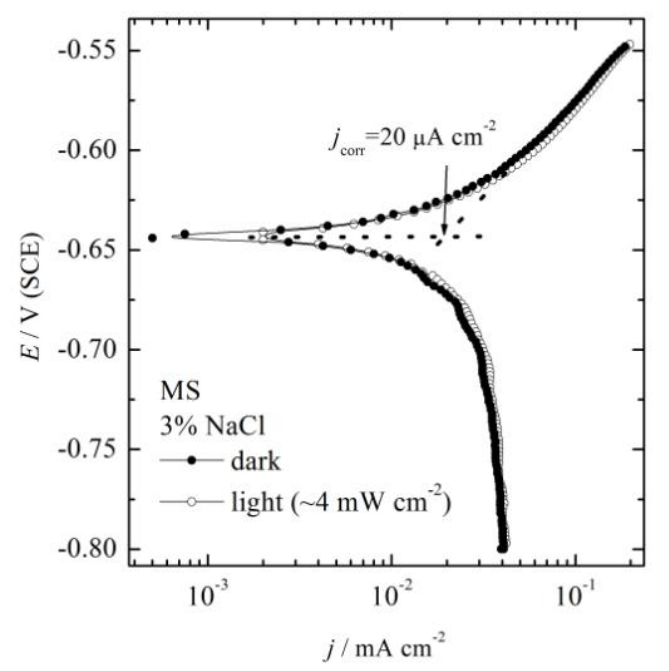

Figure 2- Polarization curves $\left(v=1 \mathrm{mV} \mathrm{s}^{-1}\right)$ of the mild steel electrode in $3 \% \mathrm{NaCl}$ under illumination $\left(4 \mathrm{~mW} \mathrm{~cm}^{-2}\right)$ and in the dark conditions.

Polyaniline was synthesized galvanostatically $(j$ $=1.5 \mathrm{~mA} \mathrm{~cm}^{-2}$ ), and dependence of potential over time of the mild steel electrode in pure $0.5 \mathrm{M} \mathrm{Na}$ benzoate solution and with the addition of $0.25 \mathrm{M}$ aniline was shown in Fig. 3.

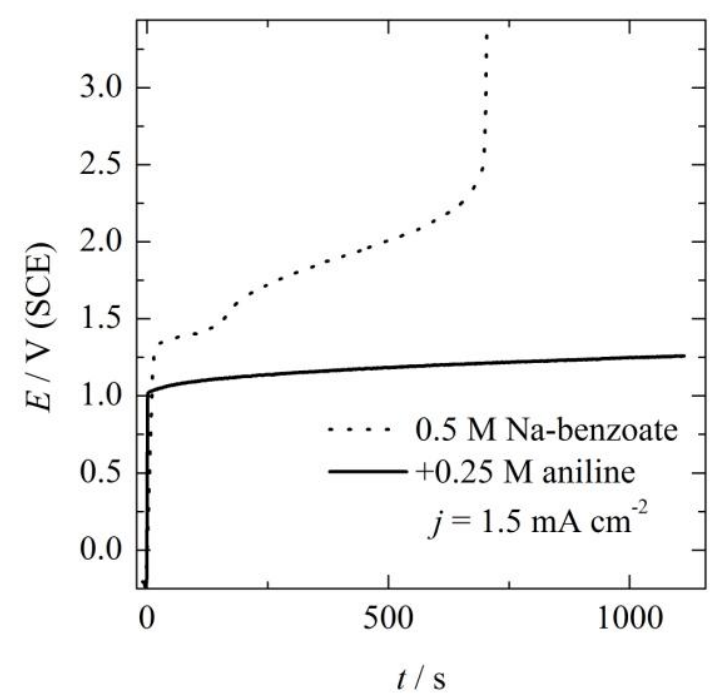

Figure 3 - Galvanostatic transient of the mild steel electrode in pure $0.5 \mathrm{M} \mathrm{Na}$-benzoate solution and with addition of $0.25 \mathrm{M}$ aniline monomer.

Without aniline in solution, potential increased from 1.3 to $2.25 \mathrm{~V}$ for $700 \mathrm{~s}$. After that period, sharp increase of the potential could indicate formation of non-conducting precipitate (e.g. ironbenzoate) onto electrode surfaces. In the solution with $0.25 \mathrm{M}$ aniline, a slow increase of the potential from 1 to $1.25 \mathrm{~V}$ could be connected with polymerization of aniline. Obtained film was black, with good adhesion, determined by cracking. Assuming the density, $\rho$, of polyaniline doped with benzoate anions of $1.4 \mathrm{~g} \mathrm{~cm}^{-3}$ [11], and using equation [12]:

$$
d=\frac{j t\left(M_{m}+y M_{a}\right)}{(2+y) \rho)}
$$

where $M_{\mathrm{m}}$ and $M_{\mathrm{a}}$ are molar mass of aniline monomer and benzoate anions, $y$ doping degree (due to the polymerization potential of $1.25 \mathrm{~V}$ PANI could be considered as pernigraniline form, $y=1$ ), the PANI thicknesses of $6 \mu \mathrm{m}$ was estimated.

With such electrode, the above described corrosion experiments were repeated. Electrode was exposed to corrosion media for 3 hours, and impedance at corrosion potential was determined. As it can be seen, from Fig. 4, were Nyquist plot of the MS-PANI electrode in $3 \% \mathrm{NaCl}$ under illumination $\left(4 \mathrm{~mW} \mathrm{~cm}^{-2}\right)$ and in dark conditions at corrosion potential was shown, illumination has effect, and accelerated corrosion. In the dark conditions overall impedance was $\sim 3000 \Omega \mathrm{cm}^{2}$, while under illumination $\sim 2550 \Omega \mathrm{cm}^{2}$.

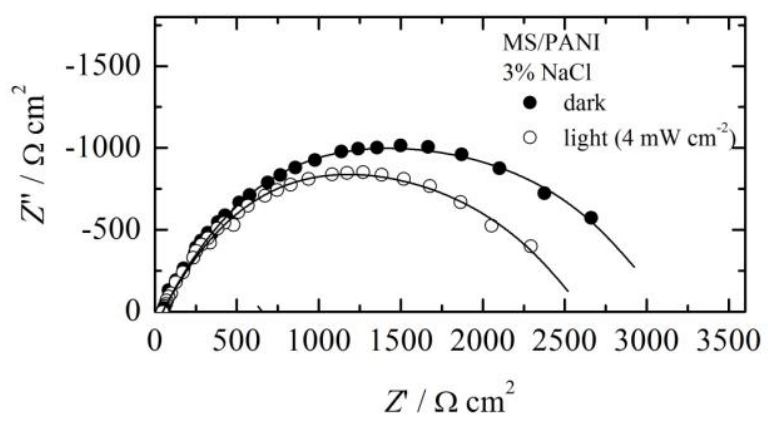

Figure 4 - Nyquist plot of the MS/PANI electrode in $3 \% \mathrm{NaCl}$ under illumination $\left(4 \mathrm{~mW} \mathrm{~cm}^{-2}\right)$ and in dark conditions at corrosion potential.

Recording polarization curves under the same conditions, the similar results were obtained. Determined corrosion current density under dark conditions was $5.7 \mu \mathrm{A} \mathrm{cm}{ }^{-2}$ and under illumination was $10 \mu \mathrm{A} \mathrm{cm}{ }^{-2}$. From the polarization curves it is obvious that illumination affects only anodic branch of the polarization curve. Cathodic branch remains practically unchanged. The insert in Fig. 5, shows the photocurrent density in the whole range of investigated potential. As it can be seen anodic photocurrent reaches few microampers near the corrosion potential. This effect is steel under investigations. But it seems that light $(h v)$ accelerates transfers of the electrons between metal-polymer surfaces. 


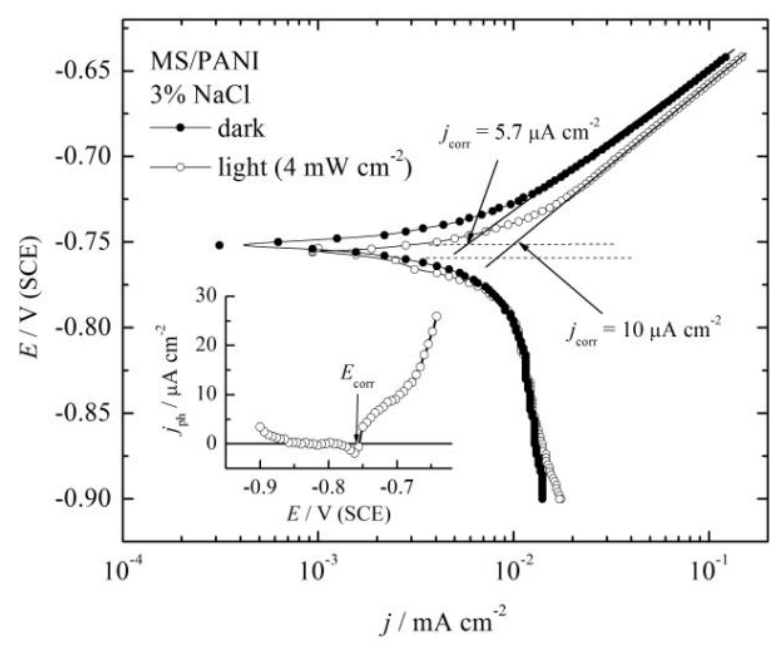

Figure 5 - Polarization curve of the MS/PANI electrode in $3 \% \mathrm{NaCl}$ under illumination $(4 \mathrm{~mW} \mathrm{~cm}$ ${ }^{2}$ ) and in dark conditions

\section{CONCLUSION}

From our simple experiments, it could be concluded that corrosion processes of steel covered with polyaniline could be affected by light intensity. In our work, mild illumination was applied $\left(4 \mathrm{~mW} \mathrm{~cm}^{-2}\right.$ ) which is the usual light intensity in laboratory conditions. Hence, any further works in application of conducting polymers in corrosion protection of metals should consider light intensity.

\section{Acknowledgement}

The research was supported by the Ministry of Education, Science and Technological Development of the Republic of Serbia, under the research project "Electrochemical synthesis and characterization of nanostructured functional materials for applications in new technologies" No. ON172046.

\section{REFERENCE}

[1] M.M. Gvozdenović, B.Z.Jugović, B.N.Grgur (2016) Nanostruktuirani elektroprovodni polimeri dobijeni elektrohemijskom sintezom, Zaštita Materijala, 57 (1), 71-79.
[2] D.E.Tallman, G.Spinks, A.Dominis, G.G.Wallace (2002) Electroactive conducting polymers for corrosion control, Part 1. General introduction and a review of non-ferrous metals, J. Solid State Electrochem., 6, 73-84.

[3] G.M.Spinks, A.J.Dominis, G.G.Wallace, D.E. Tallman (2002) Electroactive conducting polymers for corrosion control Part 2. Ferrous metals, J. Solid State Electrochem., 6, 85-100.

[4] M.Gvozdenović, B.Jugović, D.Jambrec, J. Stevanović, B.Grgur (2012) Application of polyaniline in corrosion protection of metals, Zaštita Materijala, 4, 353-360.

[5] G.G.Wallace, G.M.Spinks, L.A.P.Kane-Maguire, P.R.Teasdale (2009) Conductive Electroactive Polymers, Intelligent Polymer Systems, Third edition, CRC Press, Taylor \& Francis Group, NY.

[6] M.Kaneko, H.Nakamura (1985) Photoresponse of a liquid junction polyaniline film, J. Chem. Soc. Chem. Commun., 6, 346-347

[7] X.Wang, M.Shao, G.Shao, Z.Wu, S.Wang (2009) A facile route to ultra-long polyaniline nanowires and the fabrication of photoswitch, J. Colloid Interface Sci., 332, 74-77.

[8] P.A.Kilmartin, G.A.Wright (1996) Photoeffects at a polyaniline film electrode, Electrochim. Acta, 41(10), 1677-1687.

[9] P.A.Kilmartin, G.A.Wright (1998) Anion insertion and expulsion in polyaniline electrodes studied by photocurrent transients, Electrochim. Acta, 43(2122), 3091-3103.

[10] M.M.Popović, B.N.Grgur (2004) Electrochemical synthesis and corrosion behavior of thin polyanilinebenzoate film on mild steel, Synth. Met., 143(2), 191-195.

[11] J.Stejskal, I.Sapurina, M.Trchová, E.N Konyushenko (2008) Oxidation of Aniline: polyaniline granules, nanotubes, and oligoaniline microspheres, Macromolecules, 41, 3530-3536.

[12] J.Kankare (1998) Electrical and Optical Polymer Systems: Fundamentals, Methods, and Applications, Chapter 6, D.Wise, G.E.Wnek, D.J.Trantolo, T.M.Cooper, J.D.Gresser (Eds.), Marcel Dekker, New York.

\section{IZVOD}

\section{UTICAJ OSVETLJENOSTI NA KOROZIJU MEKOG ČELIKA SA PREVLAKOM POLIANILINA}

Ispitivan je uticaj svetlosti na koroziju mekog čelika sa prevlakom polianilina u $3 \%$ rastvoru $\mathrm{NaCl}$ sa pretpostavkom da polianilin može generisati fotoelektrone čak i u uslovima laboratorijskog osvetljenja.

Ključne reči: meki čelik; korozija; polianilin; fotoelektrohemija.

\section{Naučni rad}

Rad primljen: 23. 07. 2016.

Rad prihvaćen: 18. 08. 2016.

Rad je dostupan na sajtu: www.idk.org.rs/casopis 